症例

\title{
C 型慢性肝炎に対するインターフェロン療法後に発生した
}

\section{肝原発悪性リンパ腫}

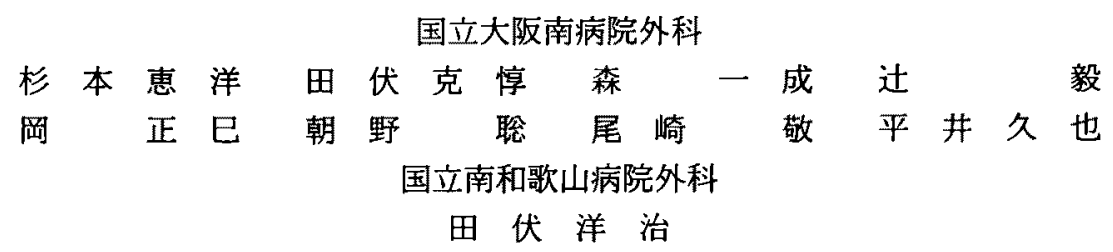

肝原発悪性リンバ腫の 1 例を経験したので報告した。症例は60歳の男性で, C 型慢性肝 炎の治燎のため interferon を投与された。投与開始 6 力月後(総投与量は 53,600 万単位) 超音波検查で肝に腫演が認められ，超音波ガイド下針生検を行った，免度組織染色の LCA と SL-26染色は陽性を，またUCHL-1，MT-1，MB-1染色は陰性を示し，病理組織 診断㤬 malignant lymphoma, diffuse, medium sized or large cell \& B cell type とさ れた。生検後 interferonは中止した。その後，腫锡は縮小傾向を示したが，生検の 42 日 後, 肝严区域切除した。摘出標本の病理組織検查では腫湯は壊死に宿っていた。手術 1 年後，全身および残肝に再発は認めない。

㮂引用語：肝原発悪性リンパ腫, 肝切除, インターフェロン

\section{緒言}

肝原発悪性リンパ腫は稀であり"1，切除例はさらに 稀である2゙。われわれは，C型慢性肝炎治療のための interferon 投与中に発見，針生検で肝㦞性リンパ腫と 診断された症例に扔いて, 肝切除を施行した。肝の切 除標本の切除組織検査ではすでに腫愓はすべて壊死に 宿っていた稀な症例を経験したので報告する．

\section{症例}

患者：60歳，男性.

主訴：無症候性肝腫㴼。

既往歴：特になし。

現病歴：健康診断で1993年11月に肝機能検查値異常 を指摘された。C型慢性肝炎のため同年12月15ゲージ 針生検で chronic active hepatitis $2 \mathrm{~B}$ ，また血液検查 でHCV-RNA $(3+)$ と診断され，1994年 1 月から interferon- $\alpha$ - $2 \mathrm{~b}$ により治療された，1千万单位を 2 週 間連日筋注，その後 6 百万単位を週 3 回 5 力月間筋注 が施行された。総投与量は 53,600 万単位であった。終 了時には血液中 HCV-RNA は陰性化した。

同年 6 月に超音波検查で肝 $S_{5} に 2.8 \mathrm{~cm}$ 大の Space

1995年 9 月29日受付 1995 年12月 8 日採用
Occupying Lesion (SOL) が発見され, 超音波ガイド 下針生検（21ゲージマジマ針を使用）により，肝原発 悪性リンパ腫と診断された後, 手術のため当科を紹介 された。

現症：身長 $159.7 \mathrm{~cm}$, 体重 $50.2 \mathrm{~kg}$. 貧血・黄疸は認 めなかった，扁桃に異常なく，頸部リンバ節など表在 リンパ節は触知しなかった，心，肺に異常はなく，腹 部は平坦, 軟で, 肝を 2 横指触知した. 脾・腎は触知 しなかった。腹水は認めなかった。

入院時検査成績 (表 1)：白血球数やその分画, 肝機 能は正常で, 腫場マーカーである AFP, CEA, CA199値も正常範囲内であった. $\mathrm{HB}$ 抗原は陰性で, $\mathrm{HCV}$ と HB 抗体が陽性であった。

腹部超音波検查：1994年 6 月16日の同検査では，肝 の $\mathrm{S}_{6}$ 区域に $2.8 \times 2.8 \mathrm{~cm} の$ 境界明瞭で内部均一な SOLを認めた。後方に腎隹胞があり，丁度よい目印に なっていた(図 1a).1力月後の7月14日には SOL は 幾分小さくなり $1.6 \times 1.5 \mathrm{~cm}$ になった（図 1b).

腹部 CT 検查（図 2a）： $\mathrm{S}_{6}$ に円形の low density area を認め，腎襄胞に接する位置にあった。造影 CT で同部は enhanceされた。他に、リンパ節腫大や脾の 異常は䜑めなかった. 
表 1 入院時検查成績

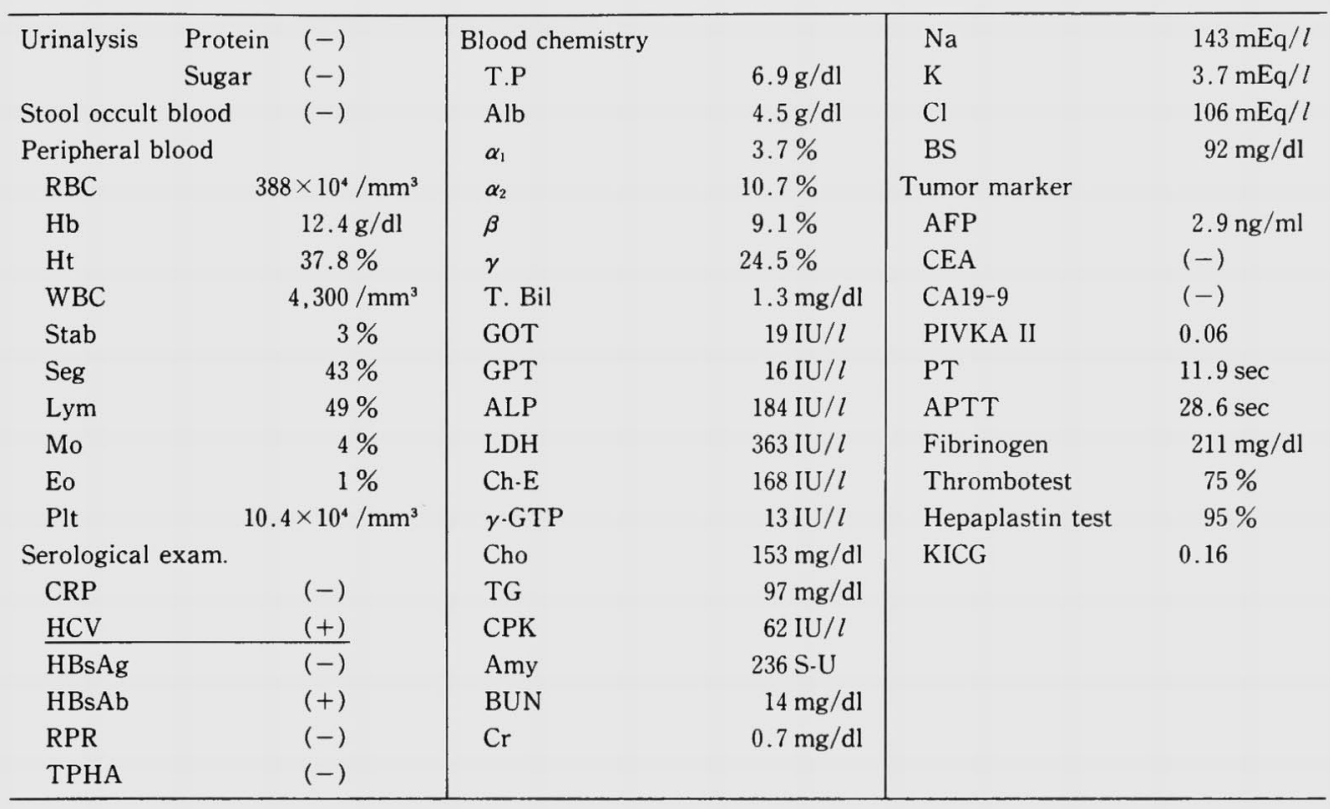

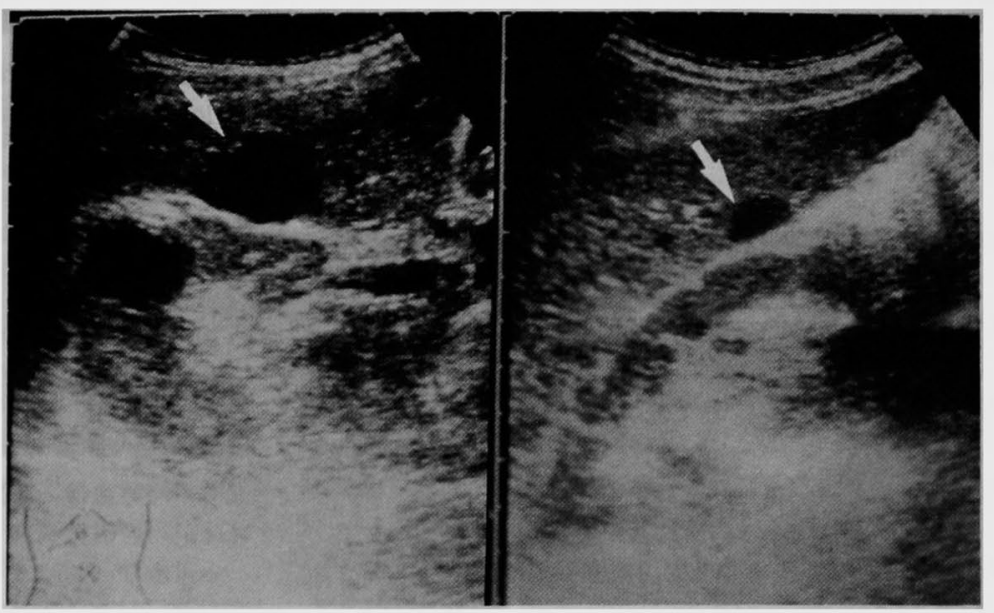

図 1 腹部超音波検査： $\mathrm{a}$ (左)：1994年 6 月 16 日, 肝の $\mathrm{S}_{6}$ 区域に $2.8 \times 2.8 \mathrm{~cm}$ の境界明 瞭で内部均一な SOL を認めた. b (右)：同年 7 月 14 日には SOL は幾分小さくなり $1.6 \times 1.5 \mathrm{~cm}$ になった.

MRI 検査（図 2b）： $\mathrm{S}_{6}$ の部位に $\mathrm{T}_{1}$ 強調画像で low, $\mathrm{T}_{2}$ 強調画像で high intensity の SOL を認めた.

腹部血管造影検查 (図 3)： $\mathrm{S}_{6}$ に動脈相では中心が hypovascular で, 辺縁がわずかに血管の造成を認め, 静脈相では $2.5 \times 2.3 \mathrm{~cm}$ のリング状の stain を認めた.

Ga シンチグラム（図 4a)：腹腔内に hot nodule は 認めなかった. しかし, 左肺野に hot nodule を認めた が, 胸部平面 X 線 (図 4b) および胸部 CT では異常を
認めなかった.

針生検病理組織検査：腫瘍の針生検の HE 染色て は細胞質の少ない, 濃染する異型性の強い核を有する 小型の異型リンパ球で構成されていた(図 5a). 免疫組 織染色の LCA とSL-26染色で diffuse に陽性を示し た(図 5b，c)。また UCHL-1，MT-1，MB-1染色は陰 性であった。以上ょり組織診断は malignant lymphoma, diffuse, medium sized or large cell \& 

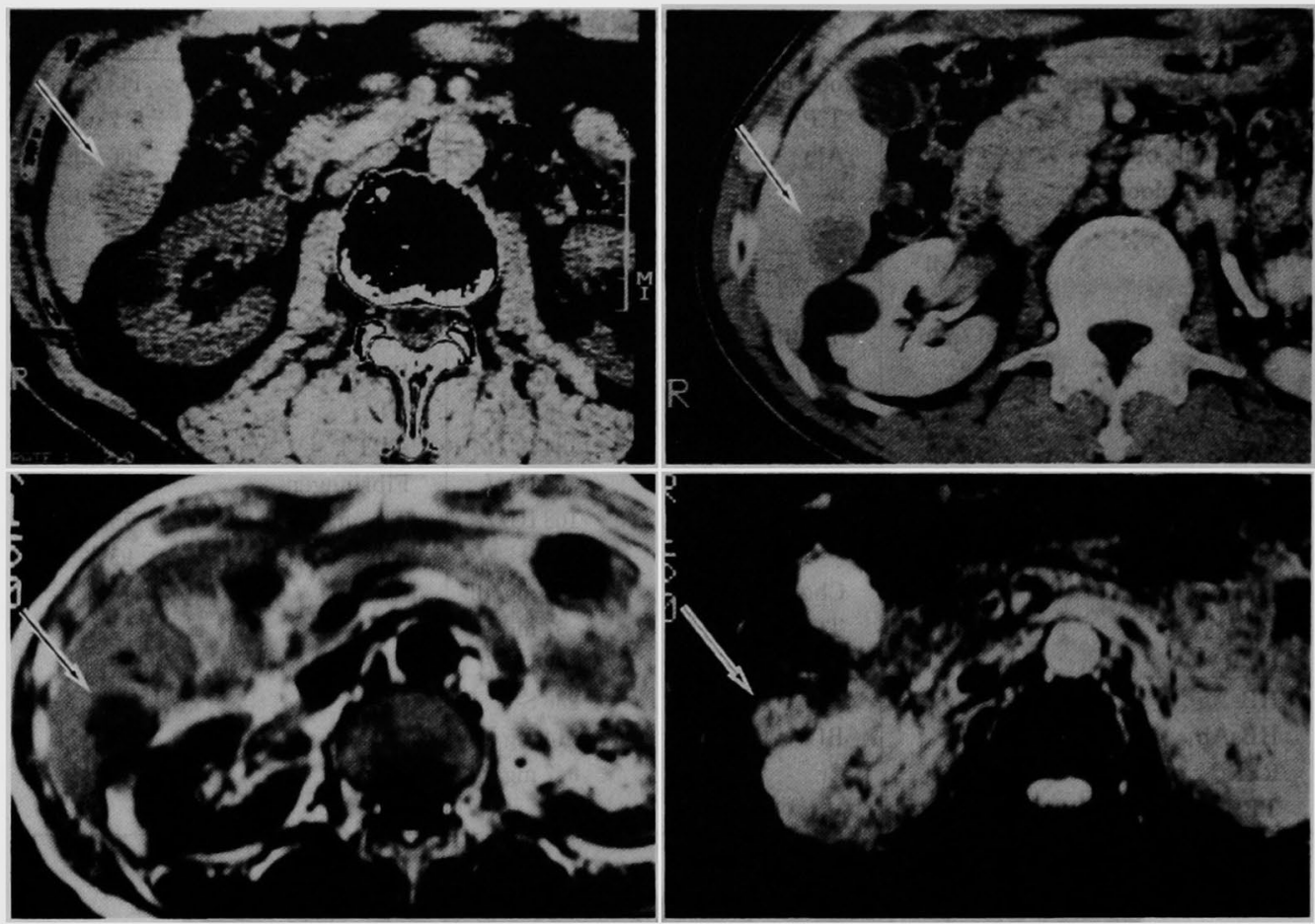

図 $2 a$ (上) 腹部 CT 検査: $\mathrm{S}_{6}$ に円形の low density area を認め, 造影 CT で enhance された. b (下) MRI 検査 : $S_{6}$ の部位に $T_{1}$ 強調画像で low, $T_{2}$ 强調画像で high intensity の SOL を認めた.

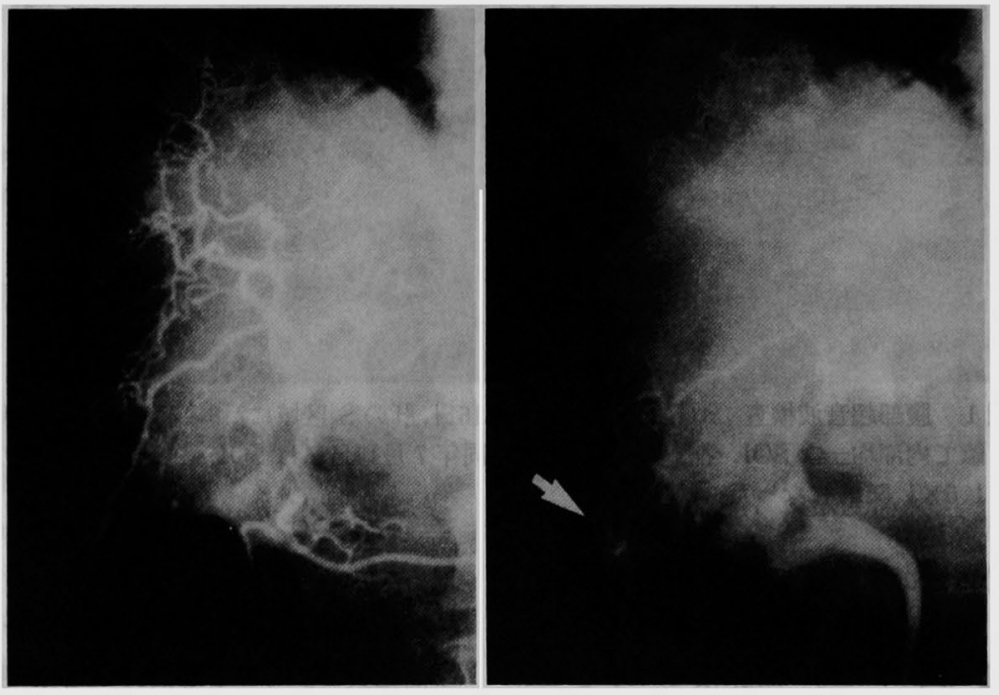

図 3 腹部血管造影検査: $\mathrm{S}_{6}$ に動脈相では中心が hypovascularで, 辺縁がわずかに 血管の造成を認め，静脈相では $2.5 \times 2.3 \mathrm{~cm}$ のリング状の stain を認めた。

B cell type とされた.

臨床経過：針生検後, 当科に紹介された。当科初診
時，超音波検査で内科初診時の $2.8 \times 2.8 \mathrm{~cm}$ 径の $\mathrm{SOL}$ が1.4×1.4cmにまで縮小傾向を示していた。 


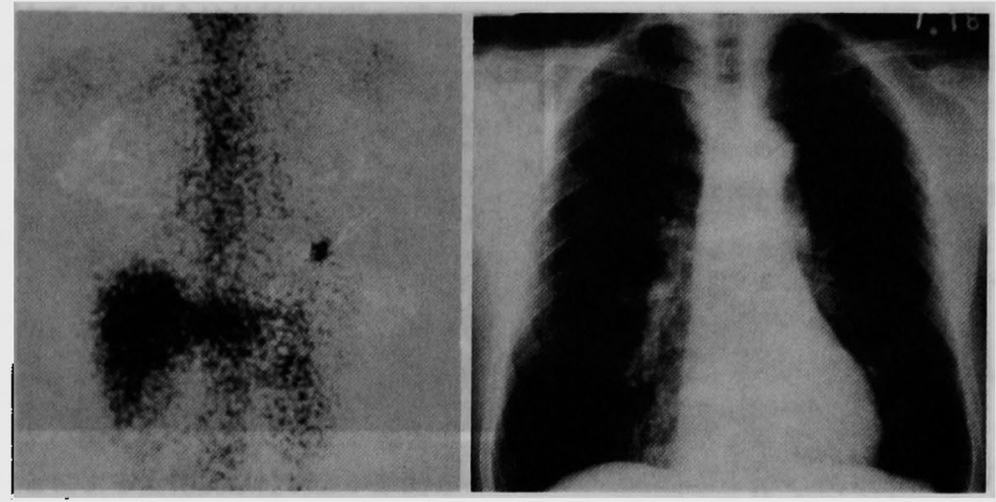

図 $4 \mathrm{a}$ (左) Ga シンチグラム：腹哚内に hot nodule は認めなかった. 左肺野に hot nodule を認めた. b (右) 胸部平面 $\mathbf{X}$ 線：異常を認めなかった.
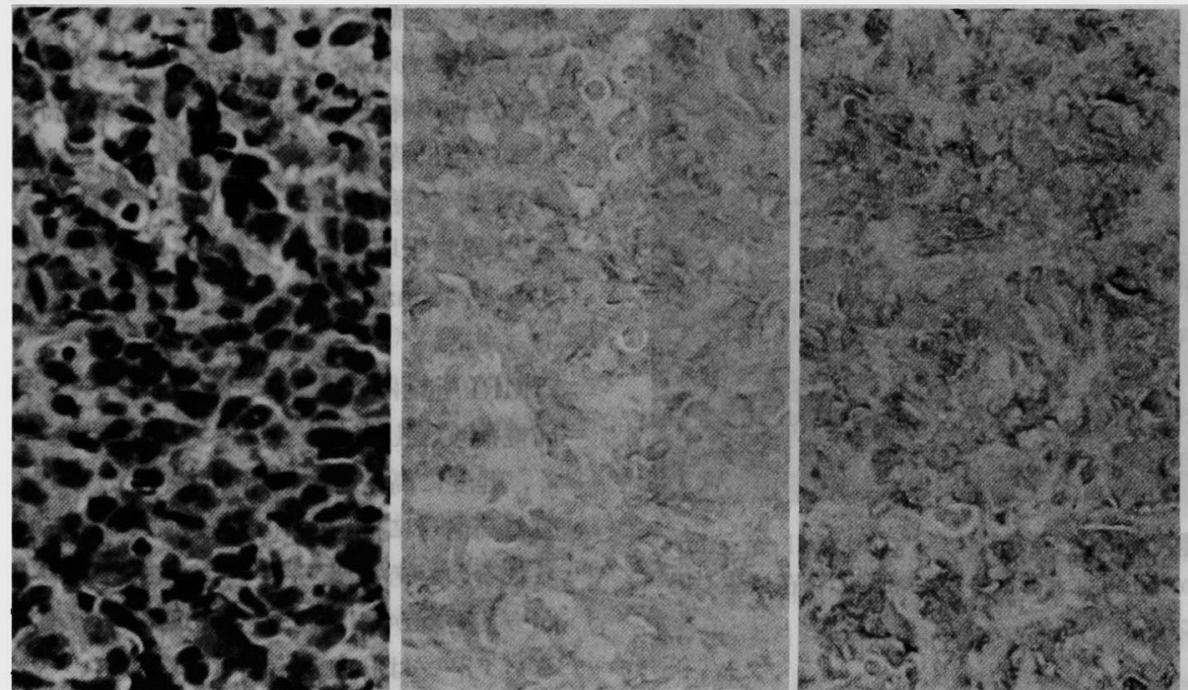

図 5 針生娭病理組織検査：a（左）HE 染色（×400）では細胞質の少ない，濃染する 異型性の強い核を有する小型の異型リン八゚球で構成されている。 b (中) LCA 染色

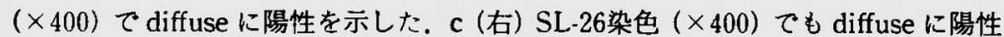
を示した。

手術：1994年 8 月 9 日肝後下亜区域切除を施行し た。術中超音波検榃においても腎莗胞に接した縮小 SOL が認められた(図 6a).また,肝の他の部位に SOL はなく，脾のエコーも正常であった，術中に腸間膜の リンパ節を生検したが，悪性細胞を認めなかった，摘 出標本では, 矢印で示した SOL は1.0×0.8 $00.8 \mathrm{~cm}$ 大で，黄色均一であった（図6b).

病理組織検查では well capsulated necrotic mass と診断され，細胞の存在は認め得なかった(図 7)。ま た,肝実質組織は mild chronic hepatitis の所見であっ
た.

術後経過：良好であった. 術 1 力月半後 $\mathrm{Ga}$ シンチ グラムを再検したが, 全く異常を認めなかった。術 3 力月後 HCV-RNA が再度陽転し, 肝炎が再燃した.し かし, interferon を投与せずに治療を行い, 軽快した。 術 1 年後の現在, 肝や全身に悪性リンパ腫の再発は認 めていない。

\section{考 察}

肝原発覀性リンパ腫の定義(3)，(1) 初回入院時蔵 器およびリンパ節転移がない, (2) 脾臓に浸潤がない, 


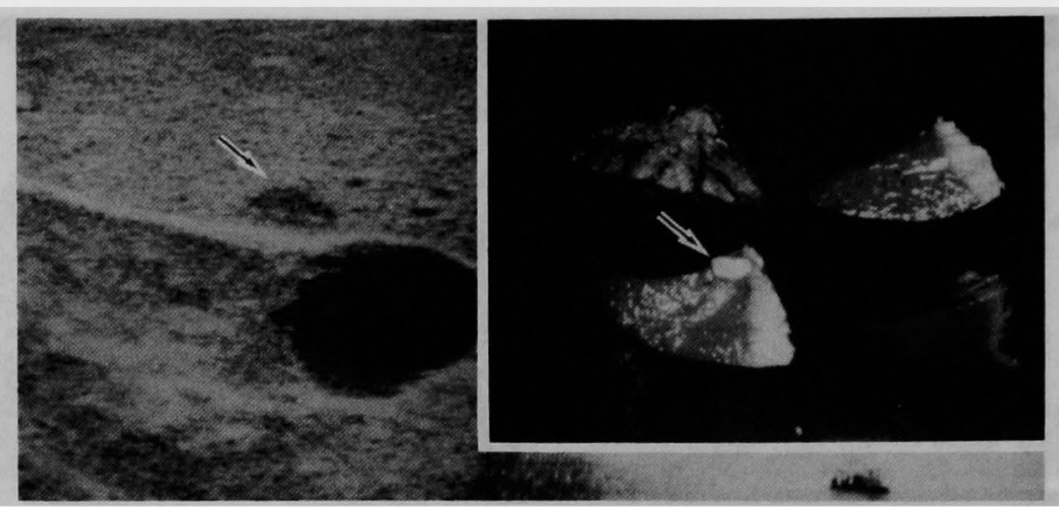

図 6 a (左) 術中超音波険査：腎重胞に接した位置に縮小した SOL が認められた. b (右) 摘出標本：SOL は $1.0 \times 0.8 \times 0.8 \mathrm{~cm}$ 大で, 黄色均一であった.

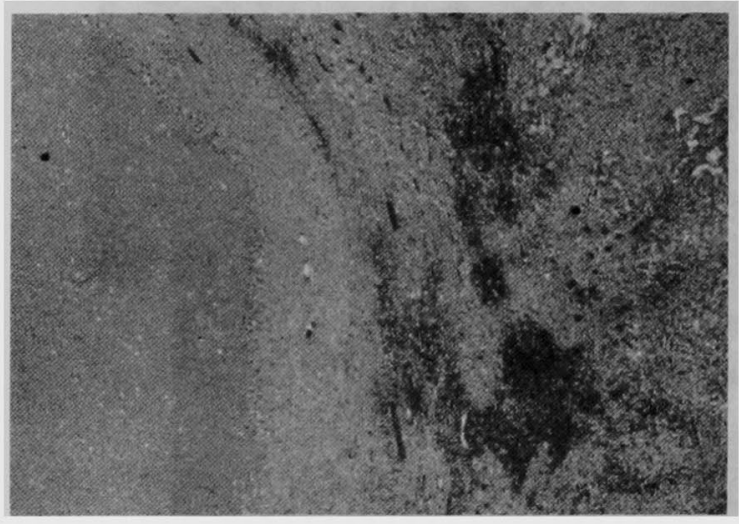

図 7 病理組織検査：(HE 染色, $\times 20)$ well capsulated necrotic mass と診断され, 細胞の存在は認め得 なかった。

（3）骨髄抑制や血液に白血病像がない，である．本症 例はこの 3 点を満足している。毛利ら”によると 30,007 体の剖検例のうち肝原発悪性リンパ腫と診断さ れた症例は 1 例もなく，極めて稀な疾患である．われ われの検索しえた範囲では英文77例, 邦文31例の計108 例の報告がある．肝切除例に限ると，英文19例，邦文 5 例の計24例である ${ }^{2 / 4}$. 108例の年齢は 0 歳から84歳 まで平均は 47.2 歳で, 特に好発年齢はない. 男女比は 3 対 1 で男性が多かった。

症状に特徵的なものはないが, 多いものとして腹部 膨满や上腹部痛, 非特異的なものとして食欲不振, 体 重減少，盗汗などがある。本例では全身倦急感を訴え たが，肝炎の症状である可能性がある.

画像診断には特徵的なものはない方．超音波検査で は多くは孤立性の境界明瞭な均一な内部の低エコー性
病変として描出される6 が，エコーでは検出されない ものや，まれに高エコーに描出されるものがある゙.し かし, 別の報告8では大きな不均一な高エコーの腫瘤 が本疾患に特徵的だと述べている。

CTでは殆どの症例で低吸収域として描出され る6). 異常吸収域として描出されるものもある5). 造影 すると, enhance されるものとされないものが同数で あった5).

MRI 所見についての記載は少ないが, 境界明瞭な限 局性病変として描出され， $\mathrm{T}_{1}$ 強調像では低信号が多 く，軽度に高信号に描出されるものもある． $\mathrm{T}_{2}$ では一 般に高信号に描出されている(19). また，分葉化が認め られるのもある". 造影で enhance されるが, 30分か かって辺縁から中心に向かって次第に全体に造影され るパターンは肝血管腫とは異なっている

血管造影検査では hypovascular がほとんどで, hypervascular はごく少数例であった ${ }^{5 / 11}$. encasement は認めない ${ }^{5}$.

以上，いずれの検查でも特徵的な所見はないが， $\mathrm{AFP}$ や CEA が陰性であることも手がかりの 1 つと なる. 最終的に確定診断は病理診断に頼らざるを得な い. 以前は剖検や開腹生検が主体であったが，次第に 腹腔鏡下生検 ${ }^{1213)}$ や超音波ガイド下針生検にとって代 られつつある.しかし，針生検は18例中，12例にしか 正診が得られず，残り 4 例は末分化な肝癌，2 例は壊 死組織であった ${ }^{41}$.十分な組織が得られる生検針の太 さが必要であろう。そして，末分化な肝紐胞癌と鑑別 するためには免疫組織学的診断が必須である"1).われ われの症例は21 gauge の針生検で腫瘍組織を得, HE 染色と免疫組織染色を行い確定診断を得た. 
治療は, 肝に限局している場合は外科的切除の適応 となる。一般に肝原発悪性リンパ腫は肝硬変を合併し ていないことが多く, 葉切以上が多い27.われわれは後 下区域に限局していたため, 覀区域切除を施行した。 結果は壊死組織であった. 生検後腫場は縮小傾向に あったのを考え併せると，自然消退と考えられる，そ の原因は不明である。

肝悪性リンパ腫の発生原因として B 型肝炎ウイル スゃAIDSの関与が推測されている". 免疫抑制状態 でEBウイルスがリンパ腫を発生させたとする報告 ${ }^{15)}$ もあり， $\mathrm{HB}_{\mathrm{s}}$ 抗原などによる慢性抗原性刺激が原因の 一つとして推測されている。C型慢性活動性肝炎に発 生したり ${ }^{16)}$, 肝硬変に合併した報告 ${ }^{17)}$ もる。われわれ の症例は C 型慢性活動性肝炎の治療のため, interferon 投与後に発見された。投与終了時, seroconversion していた. Interferonの副作用として免疫抑制状態が もたらされた可能性は否定でさない. そのような状態 下で HCV ウイルスの慢性抗原性刺激が作用したと推 測する。事実, 本例では術後 3 力月で HCV-RNA が再 度陽鞋し, 肝炎が再燃した。

B 型肝炎の治療に interferonが投与されたあとに 肝に偽リンパ腫が発生したとの報告があり，病因とし てB型肝炎ウイルスに感染した肝細胞において宿主 の免疫反応が interferonにより修飾されたため偽り ンバ腫が発生したと推論している18).

自験例で恃自然消退をみだ，その原因は不明である が, 肝生検後 interferon は投与されなかったので副作 用としての免疫抑制状態が解消し, 腫場が消失したと 推測する。

\section{結 語}

われわれは, interferon 投与後のC 型慢性肝炎の患 者の生検で免疫組織染色により肝原発性覀性リンパ腫 と診断したが, 肝切除標本で壇死と診断された症例を 経験したので報告した。

本論文の要旨は, 第157回近畿外科学会(1995年 5 月13日, 大阪）にて発表した。

\section{女献}

1) 毛利 昇：肝原発悪性リンパ腫. 日臨 46 : 989995, 1988

2) 金丸太一，宇佐見真，笠原 宏他：肝切除しえた肝 原発性覀性リンパ腫の 1 治験例と17切除症例の文 献的考察. 肝蹒 $34: 166-171,1993$

3) Aozasa K, Mishima K, Ohsawa M, : Primary malignant lymphoma of the liver. Leukemia and Lymphoma $10: 353-357,1993$

4）中原英䄈, 浅原利正, 阙本有三他：肝切除を施行し

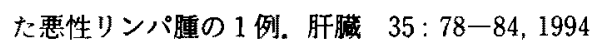

5）过龍也, 田代征記, 七川幸士郎他：原発性肝悪性 リンパ腫の 1 例。腹部画像診断 7：631-639， 1991

6) Gazelle GS, Lee MJ, Hahn PF, et al: US, CT, and MRI of primary and secondary liver lymphoma. J Computer Assisted Tomography $18: 412-415,1994$

7) Soyer P, Beers B, Thiebaud F, et al: Hodgkin' $\mathrm{s}$ and non-Hodgkin's hepatic lymphoma: Sonographic findings. Abdom Imaging 18: 339-343, 1993

8) Ginaldi S, Bernardino ME, Jing $B$, et al : Ultrasonographic patterns of hepatic lymphoma. Radiology 136 : 427-431, 1980

9) Soyer P, Beers B, Grandin C, et al: Primary lymphoma of the liver: MR findings. European J Radiology 16: 209-212, 1993

10) Shamsi $K$, Schepper $A$, Deckers F: Findings of focal hepatic lymphoma on Gd-DOTA enhanced dynamic FLASH MR imaging. Eur J Radiol $17: 88-90,1993$

11）小野 满, 石川洋子, 小岡文志地：肝原発悪性リン 八腫の 1 例. 腹部画像診断 $12: 950-956,1992$

12）園山勝久, 土屋悟史, 吉田 裕他：腹腔鏡検查にて 発見し得た肝原発性悪性リンパ腫と思われる1 例。肝荿 $23: 1237,1982$

13）湯浅圭一朗, 山田昇司, 高木 均他：腹腔鏡下肝生 検にて診断された肝原発の悪性リンパ腫の1例. 日内会誌 $75: 1616-1621,1986$

14) Zafrani ES, Gaulard $P$ : Primary lymphoma of the liver. Liver 13: 57-61, 1993

15）高橋道人：免疫毒性と発癌。免疫薬理 $10: 151$ 154,1992

16）木澤和夫, 常山幸一, 寺田忠史他：C 型慢性活動性 肝炎に合併した肝原発覀性リンパ腫の1剖検例。 日消病会誌 $90 ： 2147-2151,1993$

17）井上純一, 野村正博, 中川昌壮：肝硬変を合併した 肝原発悪性リンパ腫の 1 例。肝蔵 $28: 794-800$, 1987

18) Ohtsu $T$, Sasaki $Y$, Tanizaki $Y$, et al: Development of pseudolymphoma of liver following interferon-alpha therapy for chronic hepatitis B. Int Med $33: 18-22,1994$ 


\title{
DEVELOPMENT OF MALIGNANT LYMPHOMA OF THE LIVER FOLLOWING INTERFERON-ALPHA THERAPY FOR CHRONIC HEPATITIS C
}

Yoshihiro SUGIMOTO, Katsuyoshi TABUSE, Kazunari MORI, Takeshi TSUJI, Masami OKA, Satoshi ASANO, Takashi OZAKI and Hisaya HIRAI

Department of Surgery, Osaka-Minami National Hospital Yoji TABUSE

Department of Surgery, Minami-Wakayama National Hospital

\begin{abstract}
A 60-year-old man with biopsy-proven chronic hepatitis $\mathrm{C}$, who had been treated with human leukocyte-derived interferon-alpha (IFN $\alpha$ ) therapy for six months, was found to have a liver tumor on a routine abdominal ultrasonography examination. His liver needle-biopsy specimen showed leukocyte common antigen and SL-26 (monoclonal antibody recognizing pan-B cells) positive in immunohistochemical staining. The patient was diagnosed as having a malignant lymphoma, diffuse, medium sized or large cell \& B cell type. After the liver biopsy the administration of interferon was discontinued and then the liver tumor began to shrink. Forty-two days after the biopsy liver subsegmentectomy was performed and the tumor was histologically found to be necrotized. One year after the operation no recurrence was detected. The possible association between IFN $\alpha$ treatment and development of malignant lymphoma is discussed.
\end{abstract}

